\title{
Notes on Ordovician graptolites, nautiloids and trace fossils from Lånke, Central Nor- wegian Caledonides
}

Keywords:

- Graptolites

- Nautiloids

- Trace fossils

- Ordovician

- Caledonides

- Norway

Received:

10. December 2019

Accepted:

17. April 2020

Published online:

9. June 2020

\author{
Morten Smelror ${ }^{1}$, Terje Solbakk², Bjørn Ivar Rindstad ${ }^{1}$, Helle Vangen Stuedal ${ }^{3}$ \& \\ Karstein Hårsaker ${ }^{4}$ \\ ${ }^{1}$ Geological Survey of Norway, P.O. Box 6315 Torgarden, 7491 Trondheim, Norway \\ ${ }^{2}$ Norwegian University of Science and Technology, S.P. Andersens vei 15B, 7491 Trondheim, Norway \\ Present address: Geological Survey of Norway, P.O.Box 6315 Torgarden, 7491 Trondheim, Norway \\ ${ }^{3}$ Stjørdal Museum Værnes, Prestmovegen 2, 7500 Stjørdal, Norway \\ ${ }^{4}$ NTNU Vitenskapsmuseet, Erling Skakkes gate 47A, 7012 Trondheim, Norway \\ E-mail corresponding author (Morten Smelror): morten.smelror@ngu.no
}

Graptolites and trace fossils typical of deep-water environments are found on phyllitic roofing slates kept in the collections of the Stjørdal Museum Værnes, Trøndelag. The slates probably come from abandoned local quarries in the Stjørdal and Lånke districts. The fossils from Lånke also include some graptolites and poorly preserved nautiloids stored at the NTNU Vitenskapsmuseet, Trondheim. The graptolites indicate a Katian age, while the trace fossil assemblages compare to similar assemblages reported from the Middle-Late Ordovician Vuddudalen and Lower Hovin groups and the mostly Silurian Ekne Group of the Central Norwegian Caledonides.

\section{Introduction}

There are several records of fossils in the metasedimentary rocks of the Caledonian nappes in Trøndelag, but compared with the more shallow-marine and the less tectonically disturbed marine sedimentary strata in the Lower Palaeozoic of the Oslo Region, the recoveries of in situ body fossils have been limited (cf., overview in Spjeldnæs, 1985; Bruton \& Harper, 1988, and subsequent publications: Neuman \& Bruton, 1989; Neuman et al., 1997; Tolmacheva \& Roberts, 2007). The present note provides new information on material collected from the Lånke area (Fig. 1). The Caledonian nappes in the Upper Allochthon in Mid Norway comprise ophiolites, followed by back-arc volcano-sedimentary deposits; mainly thick successions of coarse-grained, conglomeratic and argillaceous deep-water sediments and minor tuffs (Wolff, 1979; Henriksen et al., 2018) (Figs. 1 \& 2). Fossil assemblages have to some extent been used for biostratigraphic age determinations and correlations of the various metasedimentary groups and formations, but in general the correlations rely on the lithostratigraphy. The graptolites in the present material are here (c) Copyright the authors.

This work is licensed under a Creative Commons Attribution 4.0 International License.
Smelror, M., Solbakk, T., Rindstad, B.I., Stuedal, H.V. \& Hårsaker, K. 2020: Notes on Ordovician graptolites, nautiloids and trace fossils from Lånke, Central Norwegian Caledonides. Norwegian Journal of Geology 100, 202007. https://dx.doi.org/10.17850/njg100-2-2. 


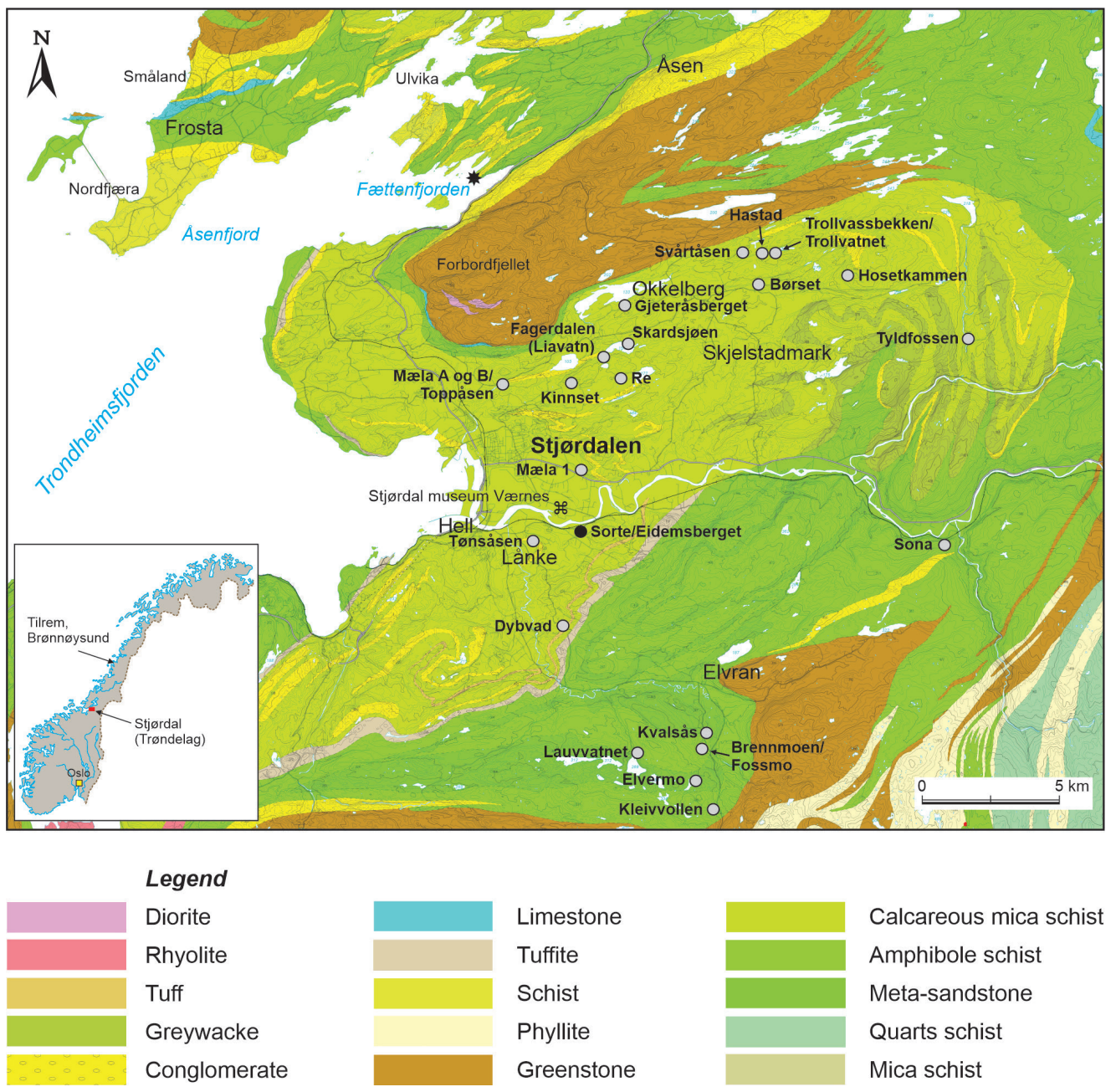

Figure 1. Bedrock map of Stjørdal, Lånke and Elvran, with locations of roofing slate quarries. Today there is production only from the Sorte Quarry at Lånke. The star at Fættenfjorden marks Locality I of Roberts (1969). Details on locations, rock compositions and previous production of the abandoned and active quarries shown on the map are found in the Geological Survey of Norway (NGU) mineral resources database: http://geo.ngu.no/kart/mineralressurser_mobil/.

tentatively correlated to Baltic graptolite zones (Fig. 3). U-Pb analyses of detrital zircons from low-grade metasandstones of the Ekne Group in the Ekne-Åsenfjord area published by Roberts et al. (2019) suggest that the succession in this area is largely of Silurian age. Assemblages of trace fossils typical of deepwater environments are more common and have been reported from the Ordovician Lower Hovin and Vuddudalen groups and the mostly Silurian Ekne Group at several localities (Torske, 1965; Roberts, 1969, 1984; Uchman et al., 2005). These ichnofossils have proved useful for interpretations of depositional environments, whereas they are of limited value for stratigraphic correlation.

In his review on biostratigraphy of the Scandinavian Caledonides, Spjeldnæs (1985) noted: "...At Lånke, south of Hell, some fossils have been found in calcareous and quartzitic mica-schists. These were nautiloids and other shelly fossils which are taxonomic indeterminable, and a few graptolites which are relatively well preserved". There are no descriptions of the localities from where the fossils were collected. The only reference given is "Spjeldnaes in Wolff 1979". In Wolff (1979), however, there are no locations given; it is only mentioned that the graptolites and nautiloids are from a quarry in Lånke (Fig. 1). Also, there is no published information on where the fossils are stored. In a search for these fossils we found out that some of the graptolites and nautiloids are kept in the collections of the NTNU Vitenskapsmuseet in Trondheim (Fig. 4). 


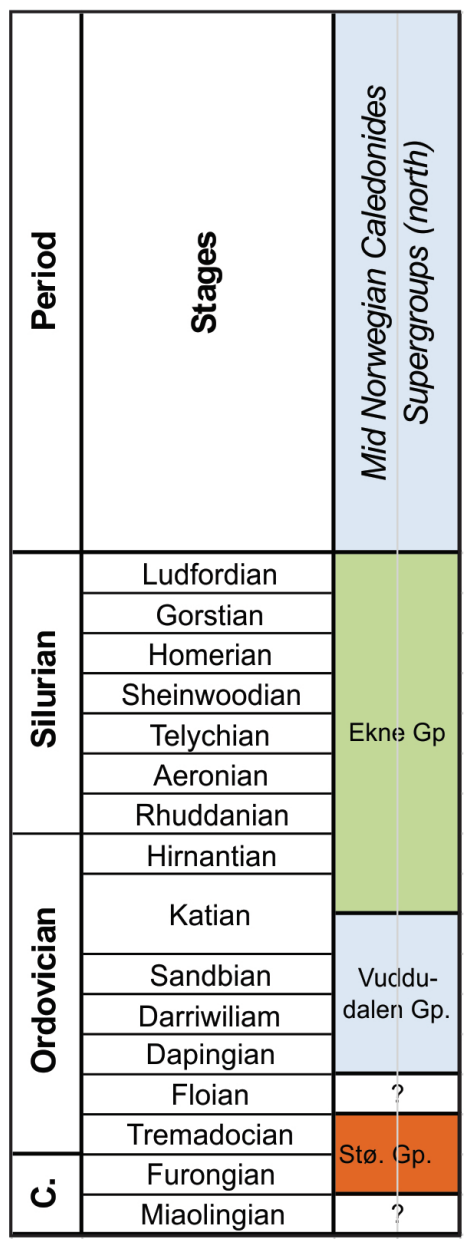

Figure 2. Simplified lithostratigraphy of the Caledonian rocks in the Stjørdal, Lånke, Elvran and Åsen areas, Central Trøndelag. Ophiolite obduction and metamorphism occurred in late Tremadocian to Floian time.

\begin{tabular}{|c|c|c|c|}
\hline \multirow{6}{*}{ 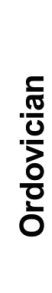 } & Hirnantian & \multirow{2}{*}{ Ekne Gp } & \\
\hline & \multirow{4}{*}{ Katian } & & $?$ \\
\hline & & \multirow{4}{*}{$\begin{array}{l}\text { Vuddu- } \\
\text { dalen Gp }\end{array}$} & Dicellograptus complanatus \\
\hline & & & Pleurograptus linearis \\
\hline & & & Dicranograptus clingani \\
\hline & Sandbian & & \\
\hline
\end{tabular}

Figure 3. Baltic Katian graptolite zones.

During previous examinations of roofing slates curated and stored at the Stjørdal Museum Værnes, we had also recognised other fossils that resemble the descriptions of the fossils reported by Spjeldnæs (1985) (Fig. 5). In the present note, we discuss possible sample locations and biostratigraphic ages of the fossils kept at the NTNU Vitenskapsmuseet (sample numbers abbreviated F), where illustrations are provided of some of the graptolites and nautiloids. We also discuss the possible origin of the fossilbearing roofing slates stored at the Stjørdal Museum Værnes. 

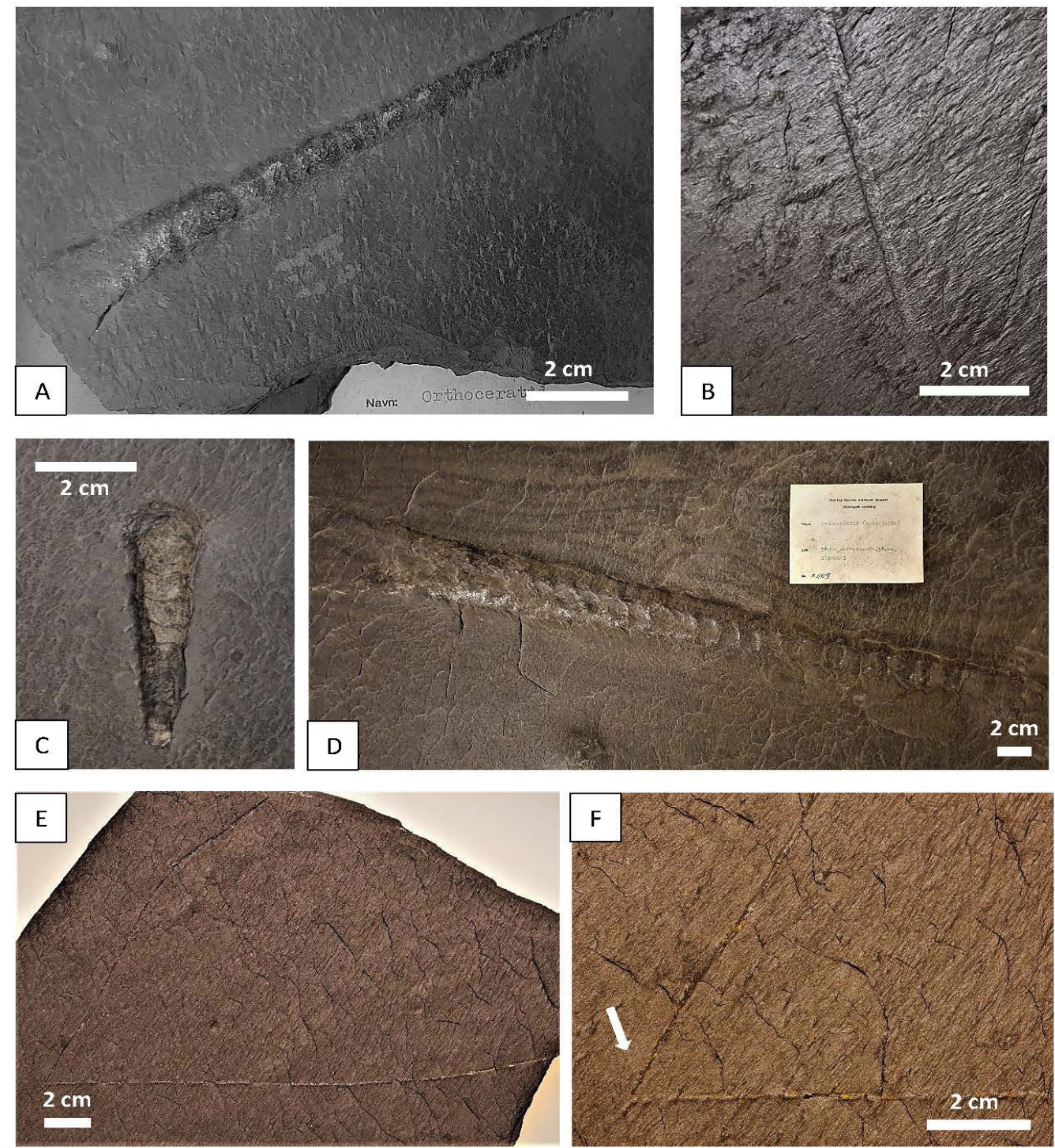

Figure 4. Nautiloids and graptolites from Lånke stored in the collections of the NTNU Vitenskapsmuseet, Trondheim. (A) Nautiloid, collection nr. F885; (B) Possible graptolite labelled Glossograptus sp. in the museum collection (Remark: most likely not this genus), collection nr. F600; (C) Nautoloid, collection nr. F888; (D) Nautoloid, collection nr. F1103 (labelled Lånke skiferbrudd, Lånke); (E and F): Dicellograptus sp. A (here assigned to D. aff. morrisi), collection nr. F601 (labelled N. Spjldnæs (sic) 1960).

\section{Graptolites}

Only two species of graptolites from Lånke were mentioned by Spjeldnæs (1985); a doubly twisted one resembling Dicellograptus caduceus and a very large one (35 cm-long branches) resembling Dicellograptus forchammeri or D. morrisi. Based on these, an age of the upper part of the Dicranograptus clingani zone or in the Pleurograptus linearis zone was indicated (Spjeldnæs, 1985), corresponding to the Katian Stage (Upper Caradoc-lowermost Ashgill). The collection at the NTNU Vitenskapsmuseet includes a graptolite labelled Dicellograptus sp. A (Fig. 4C, E) and a specimen labelled Glossograptus sp. (Fig. 4B). The first one, Dicellograptus sp. A was apparently collected by Nils Spjeldnæs in 1960 (i.e., labelled N. Spjlnæs (sic) 1960) and could possibly be the specimen mentioned to resemble Dicellograptus forchammeri or D. morrisi by Spjeldnæs (1985). According to Henry Williams (pers. comm.), D. forchammeri has more openly divergent and straight or gently flexed stipes than $D$. morrisi, and the specimen labelled Dicellograptus sp. A is probably D. morrisi, which occurs in both the Katian D. clingani and 

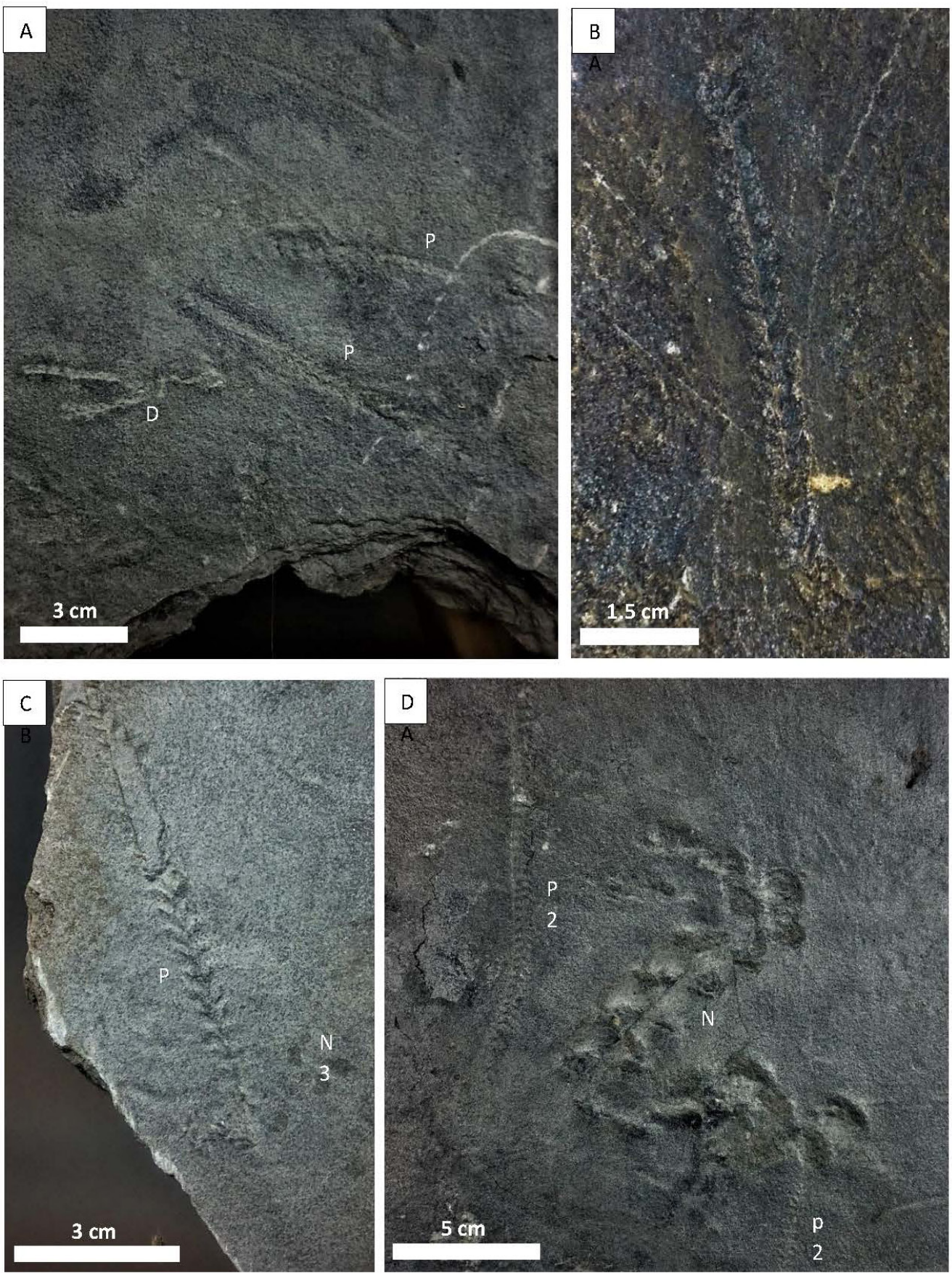

Figure 5. Graptolites and trace fossils present on roofing slates stored at the Stjørdal Museum Værnes (SNT.17499 (Primus). (A) A possible graptolite specimen, most likely Dicranograptus or Dicellograptus marked $D$, and Protovirgularia isp. marked P; (B) Protovirgularia isp.; (C) Protovirgularia isp. marked $P$, and Nereites isp. marked N; (D) Protovirgularia isp. marked $P$, and Nereites isp. marked N.

P. linearis zones in Scotland. The specimen labelled Glossograptus sp. is possibly a graptolite but has none of the characters typical of this genus (H. Williams pers. comm.).

Poorly preserved graptolites have also been found on some slates at the Stjørdal Museum Værnes. One of the slates contains a poorly preserved specimen that in overall character resembles Dicranograptus (Fig. 5A), but Dicellograptus is an alternative interpretation, since the proximal end of the specimen may be erratic. The overall poor preservation hampers further identifications of possible graptolites. 


\section{Nautiloids}

Several nautiloids from Lånke are kept in the collection of the NTNU Vitenskapsmuseet (Fig. 4A, C, D). They are, however, mostly poorly preserved. Spjeldnæs (1985) notes that "The nautiloids are (according to communication from Professor Walter C. Sweet) indeterminable both taxonomically and as to province". Some of the roofing slates examined at theStjørdal Museum Værnesalso contain poorly preserved fossils resembling orthoceratid nautiloids.

\section{Ichnofossils}

Chevron-like (stacked V) trace fossils assigned to Protovirgularia are quite common on several of the examined slates at the Stjørdal Museum Værnes (Fig. 5). Similar forms have been described under different ichnogenera, including Uchirites Macsotay, Walcottia Miller and Dyer, Rhabdoglyphus Vossoevich, Sutergichnus Chamberlain, Imbrichnus Hallam, Biformites Linck and Chevronichnus Hakes (Uchman et al., 2005). Notably, Protovirgularia has previously been interpreted as an octocoral (McCoy, 1850) and a graptolite (Richter, 1853). Moreover, this enigmatic ichnofossil has also been described as a structure produced by crabs (Gümbel, 1879), arthropods (Richter, 1941; Volk, 1961) and annelids (Richter, 1941; Claus, 1965). As pointed out by Kim et al. (2000), it was not until 1958 that Protovirgularia was convincingly established as an ichnofossil by Häntzschel (1958).

Seilacher \& Seilacher (1994) have demonstrated that Protovirgularia probably was produced by burrowing bivalves in, or crawling on, soft substrates. According to Nara \& Ikari (2011), Protovirgularia is now widely regarded as a locomotive trace of the protobranchs or scaphopods that have a bilobate foot. The ichnogenus is found in deep-marine to shallow-marine, and even glacio-marine and non-marine environments (Kim et al., 2000; Ekdal \& Bromley, 2001; Gibert \& Domènech, 2008; Nara \& Ikari, 2011; Luo \& Shi, 2017).

Uchman et al. (2005) reported that the stratigraphic range of Protovirgularia is Arenig to Miocene. A correlation to the British Arenig Series and the ICS Florian and Dapingian Stages (latest Early-Middle Ordovician) or younger Ordovician fits with the previous age assignments of the Lower Hovin and Ekne groups in the Central Norwegian Caledonides. However, according to Luo \& Shi (2017), Protovirgularia is also known from Cambrian deposits.

Some simple trace fossils present on the Stjørdal Museum slates (not figured) are comparable to ?Planolites previously reported from Fættenjorden (Fig. 1), or ?Helminthopsis reported from Mæla B (Fig. 1) by Uchman et al. (2005). The museum slates also contain several trace fossils assigned to Nereites (Fig. 5C, D), possibly N. missouriensis, which is reported from similar roofing slates at Tilrem in Brønnøysund, Nordland (Uchman et al. 2005) (see location inserted in Fig. 1). Some trace fossils figured as possible arthropod tracks from the Ekne Group in Fagerdalen (Fig. 1) by Roberts (1969) are similar to Nereites. This ichnogenus is characteristic in bathyal to abyssal deposits and has also been described from Fættenfjorden by Roberts (1984). Traces that can be attributed to Nereites missouriensis are present in situ at Tønsåsen, Lånke (Fig. 1), occurring in thin-bedded sandstones and shales of the Ekne Group.

\section{Origins of the slates and fossils}

In the Lånke area and the adjacent Stjørdalen there has been a considerable production of light- to medium-grey and dark grey to black roofing slates from several quarries (Fig. 1). According to Dahle et al. (2017), the first slate quarries in the region where opened in the late eighteenth century. A hundred years later 19 quarries were in operation at the same time (Helland, 1893). Square slates for roof covering 
were made from approximately 1840. Everyone from large-scale producers with several employees and industrially driven quarries, to single persons working alone, put standardised slate tiles into a local and regional market (Leirfall, 1972). Due to the structure of this market and the tendency to move houses and reuse and mix stocks of slate tiles, geological knowledge and methods seem to be the best way to relate single tiles to specific geological locations. Today, very few quarries are active, and at Lånke only the Sorte Quarry is still producing, and delivering several products from rocks of different colours and textures.

The largest and thickest slates stored at the Stjørdal Museum Værnes resemble grey and greenish-grey phyllitic roofing slates from the quarries near Okkelberg and west of Skjelstad. The quarry at Hosetkammen (Fig. 1) started production around 1830, with slates typically 1.5 to $3 \mathrm{~cm}$ thick. At Gjeteråsberget the year 1884 is visible etched on the quarry wall.

Large, thick and solid roofing slates, traditionally named "60 × 60 alen slates", were quarried at the farm Børset in Skjelstadmarka. These were phyllitic shales which vary from very dark to light grey, to greenish/ bluish-grey in colour. Most shales from the Børset quarry are lighter in colour than the average slates from the Stjørdal and Lånke districts. The texture and colour of the largest and solid slates with fossils at the Stjørdal Museum Værnes closely resemble typical phyllitic shales from the quarry at Børset.

However, some of the slates in the Stjørdal Museum might also have come from the quarries closer to Lånke, including Sorte and Mæla. The Mæla quarry typically contains dark grey to black phyllite. Dark grey to black slates are also typical of some of the abandoned quarries south of Elvran; such as Brennmoen, Fossmo and Kvalsås (Fig. 1). Thin and dark grey to black slates typically are found near Tyldfossen in Flora, but layers of dark shale, with common pyrite, are found in many places in the Stjørdalen-Lånke districts, and the collection at NGU also contains dark slates from the Sorte Quarry. In conclusion, the exact provenance of the unmarked roofing slates stored at the Stjørdal Museum Værnes is difficult to point out, although the small Børset quarry in northern Skjelstadmark appears to be the provenance for the fossil-bearing " $60 \times 60$ alen slates", referring to the traditional Norwegian measure alen, equal to 62 centimetres.

We note that Uchman et al. (2005) illustrate Protovirgularia dichotoma on parting surfaces on roofslates from Tilrem, a farm near Brønnøysund (Fig. 1). The Protovirgularia shown by Uchman et al. (2005) are very similar to the ones seen on slates at the Stjørdal Museum Værnes. The slates at Tilrem were used on a vicarage roof at Vassås in Bindal, south of Brønnøysund, dating from about 1870. The original provenance is not known, but presumably they come from an unknown, abandoned slate quarry located east of Trondheimsfjorden (Uchman et al., 2005).

The only record of a precise location for the graptolites and nautiloids stored at NTNU Vitenskapsmuseet is a single specimen labelled collected by Spjeldnæs 1960. According to the collection label, this comes from "Lånke skiferbrudd". This is an imprecise location name, given the large number of quarries in the Lånke area. However, based on colours and texture, most of the fossil-bearing micaceous slate samples stored at the NTNU Vitenskapsmuseet possibly come from the Sorte Quarry (Fig. 1).

\section{Ages and correlations}

The probable Katian graptolite Dicellograptus morrisi from Lånke is somewhat younger than the welldocumented Llanvirn-Arenig graptolite faunas found at Bogo in the Løkken-Meldal area (Blake, 1962; Skevington, 1963; Berry, 1968; Ryan et al., 1980; Schmidt, 1984, 1987; Schmidt-Gündel, 1994). In addition to the Katian graptolites mentioned by Spjeldnæs (1985) and the one confirmed in the collection at NTNU Vitenskapsmuseet (Fig. 4E, F), corals of Sandbian to early Katian age (Caradoc) are 
found in a limestone quarry at Åsen (Fig. 1), north of Stjørdal (Wolff, 1979). Limestones on the nearby Frosta peninsula have yielded conodonts of Katian age (Tolmacheva \& Roberts, 2007). These are assigned to the Vuddudalen Group (Henriksen et al., 2018), which is stratigraphically below the Ekne Group but postdates the Tremadocian-Furongian Forbordfjell ophiolite (Gromet \& Roberts, 2016).

The graptolite which resembles Dicranograptus, found on the Stjørdal Museum Værnes slate, also indicates a Katian age (Uchman, pers. comm.). Unfortunately, the exact location of the slates with graptolite remains is presently not known, and the stratigraphic positions within the Lower Hovin Group and/or lowermost Ekne Group cannot be determined. Possibly the fossils stored at the NTNU Vitenskapsmuseet labelled "Lånke Quarry" come from the Sorte Quarry. The rocks at the Sorte Quarry are thinbanded metasandstone and alternating dark grey, thinly laminated slate and phyllite assigned to the Ekne Group. A Katian age for this part of the Ekne Group at this location, however, cannot be confirmed at present. Based on the U-Pb zircon datings on sandstone samples from the Ekne-Åsenfjorden area (Roberts et al., 2019), only the lowermost part of the group is likely to be of Katian-Hirnantian age, with the bulk of the $2.8 \mathrm{~km}$-thick succession being clearly Silurian.

There is a need, and potential, for new discoveries of in situ fossils in the Caledonian rocks of the Stjørdal and Lånke areas. Records of graptolites are mentioned in several notes and litterature of local history, although there are no published determinations of any taxa. A few diplograptids are reported from slates from the Fossmo Quarry (Fig. 1), but further studies are needed to confirm the unauthorised and unpublished records.

\section{Conclusions}

Research on phyllitic roofing slates stored at the Stjørdal Museum Værnes has revealed assemblages of graptolites and trace fossils typical of deep-water environments. The roof-slates probably originate from abandoned local quarries in the Stjørdal and Lånke districts, but the precise provenances of the slates are presently not known. The graptolites and nautiloids mentioned by Spjeldnæs (1985) possibly originates from the Sorte Quarry in Lånke. The graptolites stored at the NTNU Vitenskapsmuseet appear to indicate a Katian age, while the trace fossils found on the slates at Stjørdal Museum Værnes compare to trace fossil assemblages reported from the Vuddudalen and Ekne groups of this part of the Central Norwegian Caledonides. The findings suggest that rich assemblages of trace fossils, and probably also some graptolites and other body fossils, are to be found in several of the historical quarries and adjacent areas with metasedimentary rocks in the Stjørdalen - Lånke areas.

Acknowledgements. Thanks are due to drs. Dirk Knaust (Equinor), Jörg Maletz (Freie Universität Berlin), Alfred Uchman (Jagiellonian University) and Henry Williams (Suncor Energy) for guidance and comments on the identifications of the examined specimens. The identifications and taxa assignments, however, have not necessarily been agreed upon among our colleagues, and the current presentation rests on the interpretations given by the responsible authors. The authors also thank the Stjørdal Museum Værnes and NTNU Vitenskapsmuseet for assistance and access to the collections. The helpful comments provided by David L. Bruton on an earlier version of the manuscript and the most constructive reviews by Magne Høyberget are highly appreciated. 


\section{References}

Berry, W.B.N. 1968: Age of Bogo Shale and western Ireland graptolite faunas and their bearing on dating early Ordovician deformation and metamorphism in Norway and Britain. Norsk Geologisk Tidsskrift 48, 217-230.

Blake, D.H. 1962: A new Lower Ordovician graptolite fauna from the Trondheim Region. Norsk Geologisk Tidsskrift 42, 223-238.

Bruton, D.L. \& Harper, D.A.T. 1988: Arenig-Llandovery stratigraphy and faunas across the Scandinavian Caledonides. In Harris, A.L. \& Fettes, D.J. (eds.): The Caledonian-Appalachian Orogen. Geological Society Special Publication 38, 247-268. https://doi.org/10.1144/GSL.SP.1988.038.01.15.

Claus, H. 1965: Eine merkwürdige Lebensspur (Protovirgularia? sp.) aus dem oberen Muschelkalk NW-Thüringens. Senckenberg Lethaia 46, 187-191.

Dahle, K., Grytli, E.R. \& Nilsen, D. 2017: Trønderlåna hus, heim, identitet og kultur. Embla Forlag AS.

Ekdal, A.A. \& Bromley, R.G. 2001: A day and a night in the life of a cleft-foot clam: ProtovirgulariaLockeia-Lophoctenium. Lethaia 34, 119-124. https://doi.org/10.1080/00241160152418410.

Gibert, J.M. de \& Domènch, R. 2008: Trazas fósiles de nuculoideos (Protovirgularia) del Mioceno marino de la Cuenca del Vallè Penedés. Revista Espaňola de Paleontologia 23, 129-138.

Gromet, L.P. \& Roberts, D. 2016: U-Pb zircon ages of felsic rocks in the Fordbordfjell ophiolite fragment, Støren Nappe, Mid-Norwegian Caledonides. Norwegian Journal of Geology 96, 301- 309.

Gümbel, C.W. 1879: Geognostische Beschreibung de Fichtelgebirge smit dem Frankenwalde und dem westlichen Vorland. Justus Perthes Gotha, 698 pp.

Häntzschel, W. 1958: Oktokoralle oder Lebensspur? Geologisches Staatsinstitut in Hamburg, Mitteilungen 27, 77-87.

Helland, A. 1893: Tagskifere, heller og vekstene, Geological Survey of Norway 10, 178 pp.

Henriksen, S., Roberts, D. \& Pedersen, P.-Å. 2018: Turbidite and conglomerate successions in an Ordovician back-arc basin, Mid-Norwegian Caledonides: a result of long-term staging followed by catastrophic release of sediments. Norwegian Journal of Geology 98, 141-164.

https://doi.org/10.17850/njg98-1-09.

Kim, J.-Y., Kim, K.-S. \& Pickerill, R.K. 2000: Trace Fossil Protovirgularia McCoy, 1850 from Nonmarine Cretaceous Jinju Formation on the Sacheon area, Korea. Journal of the Korean Earth Science Society 21, 695-702.

Leirfall, J. 1972: Liv og lagnad i Stjørdalsbygdene. Stjørdalsboka bind I, del III. Published by Stjørdal og Meråker kommuner.

Luo, M. \& Shi, G.R. 2017: First record of the trace fossil Protovirgularia from the Middle Permian of southeastern Gondwana (southern Sydney Basin, Australia). Alcheringa 41, 335-349. https://doi.org/10.1080/03115518.2017.1283052. 
McCoy, F. 1850: On some genera and species of Silurian Radiata in the collection of the University of Cambridge. Annals and Magazine of Natural History (Series 2) 6, 270-290.

Nara, M. \& Ikari, Y. 2011: “Deep-sea bivalvian highways": An ethological interpretation of branched Protovirgularia of the Palaeogene Muroto-Han-to Group, southwestern Japan. Palaeogeography Palaeoclimatology Palaeoecology 305, 250-255. https://doi.org/10.1016/j.palaeo.2011.03.005.

Neuman, R.B. \& Bruton, D.L. 1989: Brachiopods and trilobites from the Ordovician Lower Hovin Group (Arenig/Llanvirn), Helonda area, Trondheim Region, Norway: new and revised taxa and paleogeographic interpretation. Geological Survey of Norway Bulletin 414, 49-89.

Neuman, R. B., Bruton, D. L. \& Pojeta, J. Jr. 1997: Fossils from the Ordovician 'Upper Hovin Group' (Caradoc-Ashgill), Trondheim Region, Norway. Geological Survey of Norway Bulletin 432, 25-58.

Richter, R. 1853: Thüringer Graptolithen. Deutsche Geologische Gesellschaft, Zeitschrift 5, 439-464.

Richter, R. 1941: Marken und Spuren im Hunsrickshiefer. 3. Fährten als Zeugnisse des Lebens auf dem Meeres-Gunde. Senckenberg 23, 218-260.

Roberts, D. 1969: Trace fossils from the Hovin Groups, Nord-Trøndelag, and their bathymetric significance. Geological Survey of Norway Bulletin 258, 228-236.

Roberts, D. 1984: Nerites from the Ordovician rocks of the eastern Trondheimsfjord area, Central Norwegian Caledonides. Geological Survey of Norway Bulletin 396, 43-45.

Roberts, D., Morton, A. \& Frei, D. 2019: A Silurian age for the metasedimentary rocks of the Ekne Group, Trøndelag, Mid-Norwegian Caledonides: and inferences for a peri-Laurentian provenance. Norwegian Journal of Geology 99, 1-13. https://doi.org/10.17850/njg99-4-3.

Ryan, P.D., Willams, D.M. \& Skevington, D. 1980: A revised interpretation of the Ordovician stratigraphy of $S \varnothing r-T r ø n d e l a g$ and its implications for the evolution of the Scandinavian Caledonides. In Wones, D. R. (ed.): The Caledonides in the USA. Proceedings of the International Geological Correlation Program - Caledonide Orogen Project 27, Blacksburg, VA. Department of Geological Sciences, Virginia Polytechnic Institute and State University, Memoir No. 2, pp. 99-103.

Schmidt, O. 1984: The graptolitic facies of the Bogo Shale (Arenig-Llanvirn), Sor-Trondelag, west central Norway. Geologica et Palaeontologica 15, 17-19.

Schmidt, O. 1987: Lower Ordovician graptolite fauna of the Bogo Shale (West Norway), and its paleogeographical relationships. Bulletin Geological Society, Denmark 35, 209-215.

Schmidt-Gündel, O. 1994. Die unterordovizischen Graptolithenfaunen des Bogo- und Lo-Schiefers (Sør-Trøndelag, West-Norwegen). PhD thesis, Technische Universität Berlin, 257 pp.

Seilacher, A. \& Seilacher, E. 1994: Bivalvian trace fossils: a lesson from actuopalaeontology. Courier Forschungsinstitut Senckenberg 169, 5-15.

Skevington, D. 1963: A note on the age of the Bogo Shale. Norsk Geologisk Tidsskrift 43, 257-60.

Spjeldnæs, N. 1985: Biostratigraphy of the Scandinavian Caledonides. In Gee, D.G. \& Sturt, B.A. (eds.): 
The Caledonide Orogen - Scandinavia and related areas. John Wiley \& Sons, Chichester, pp. 317-329. Tolmacheva, T. Ju. \& Roberts, D. 2007: New data on Upper Ordovician conodonts from the Trondheim Region, Central Norwegian Caledonides. Geological Survey of Norway Bulletin 447, 5-15.

Torske, T. 1965: Geology of the Mostadmarka and Selbustrand area, Trøndelag. Geological Survey of Norway Bulletin 232, 1-83.

Uchman, A., Hanken, N.-M. \& Binns, R. 2005: Ordovician bathyal trace fossils from metasiliciclastics in central Norway and their sedimentological and paleogeographical implications. Ichnos 12, 105-133. https://doi.org/10.1080/10420940590914534.

Volk, M. 1961: Protovirgularia nereitarum (Reinhard Richter), eine Lebensspur aus dem Devon Thüringens. Senckenberg Lethaia 42, 69-75.

Wolff, F.C. 1979: Beskrivelse til de berggrunnsgeologiske kart Trondheim og $\emptyset$ stersund, scale 1:250,000 (Med fargetrykte kart), Norges geologiske undersøkelse 353, 1-76. 